\title{
Não há Pecado ao Sul do Equador: Histórias de Amor Construindo o Brasil
}

Ana Claudia Aymoré Martins*

Universidade Federal de Alagoas

Para Renato Cordeiro Gomes

\begin{abstract}
Resumo
O artigo trata das relações entre a construção simbólica da identidade nacional no Brasil e as histórias de amor que perpassam três textos literários - a Iracema, de José de Alencar, $O$ Cortiço, de Aluísio Azevedo e O Xangô de Baker Street, de Jô Soares - analisando-os à luz de eixos dominantes do discurso cultural brasileiro, como os da cordialidade, da decadência, da mestiçagem, da originalidade e da subversão às normas.
\end{abstract}

Palavras-chave: nação, identidade nacional, literatura brasileira, história cultural, Brasil

\section{Abstract}

The article concerns possible relations between the symbolic construction of national identity in Brazil and the love stories that go through three literary texts - José de Alencar's Iracema, Aluísio Azevedo's O Cortiço and Jô Soares' O Xangô de Baker Street - enlightening the reading with some of the dominant axis of Brazilian cultural discourse, such as cordiality, decay, miscegenation, originality and subversion of the standards.

Key words: nation, national identity, Brazilian literature, cultural history, Brazil

\section{Misturação e preconceito}

\author{
"Ocê tem buniteza \\ E a natureza foi quem agiu \\ Com esses óio de índia \\ Curare no corpo \\ Que é bem Brasil \\ Tu é toda Bahia \\ É a flô do mucambo \\ Da gente de cô \\ Faz do amor confusão \\ Numa misturação \\ Bem banzeira e inzoneira \\ Que tem raça e tradição"
}

Bororó: "Curare"

Em outubro de 1940, o "cantor das multidões" Orlando Silva lançava mais uma canção que rapidamente se tornaria sucesso popular: o choro estilizado "Curare", de autoria de Alberto Simoens (Bororó). Primeiro grande astro da música brasileira a surgir após a invenção do microfone, Orlando era acusado por seus opositores de ser "americanizado", devido à influência do jazz norte-americano (e de Bing Cosby em particular) nos arranjos de seu repertório e no estilo mais casual de cantar, que contrastava com a tradição do

\footnotetext{
* Graduada e Mestre em História Social da Cultura pela Pontifícia Universidade Católica do Rio de Janeiro (1993), e doutora em Letras (Ciência da Literatura) pela Universidade Federal do Rio de Janeiro (2003). Atualmente é professora adjunto da Universidade Federal de Alagoas.
} 
"vozeirão" entre os cantores de projeção nacional - como o que havia garantido o sucesso absoluto de um Chico Alves. Em larga medida, as atitudes de Orlando, após alcançar o estrelato, corroboravam esta tese da "imitação das novidades que vinham do estrangeiro" e do conseqüente mascaramento de seu "ser brasileiro": mulato e pobre de nascimento, passou a encobrir essas origens no apuro do vestuário, nos cabelos cuidadosamente gomalinados, no falar difícil (CASTRO, 1987).

No entanto, as escolhas de Orlando em sua vida particular nem sempre se refletiam na música: paradoxalmente, quanto mais escondia o mestiço sob a brilhantina e os ternos bem cortados, mais se esforçava por "cantar o Brasil", em suas formas mais diversas. Assim, ao lamento sertanejo de "Cabocla", sucedia-se a euforia brincalhona de "A jardineira", marchinha típica do carnaval carioca; ao sentimentalismo rasgado de "História joanina" sobrepunha-se a bossa sestrosa de "Dama do cabaré"; enfim, para além das valsas e fox-trotes que o celebrizaram para a posteridade, Orlando era também o cantor dos sambas, choros e marchas que (d)escreviam certos Brasis, seja na imagem alegre, já pasteurizada e vendida para o estrangeiro, do "paraíso da mestiçagem", seja no aspecto triste ou irônico de suas contradições.

Sem dúvida, "Curare", tal como pensada por Bororó, pertence à primeira destas concepções de Brasil que perpassavam o discurso cultural da época, e que tiveram como marco a composição, entre as décadas de 1930 e 1940, de uma série de "sambas-exaltação", como "Aquarela do Brasil" de Ari Barroso, "O que é que a baiana tem?" de Dorival Caymmi e "Brasil Pandeiro" de Assis Valente". A imagem da mulher-natureza, na forma da índia com "curare no corpo" - portanto, ao mesmo tempo símbolo da pureza e da tentação representa o fator nativo, original (inspirado, sem sombra de dúvida na Iracema

\footnotetext{
${ }^{1}$ No contexto de implantação da política de boa vizinhança, os sambas-exaltação acabaram por tornar-se pontes entre o desejo de "afirmação da brasilidade" e o gosto (ou a necessidade, para fins estratégicos e econômicos) norte-americano pelo "exótico tropical", como podemos ver nos três exemplos citados. Composta em 1939, a canção de Ari Barroso acabou se convertendo em uma espécie de "hino informal" de um Brasil antropomorfizado em "mulato inzoneiro", vindo a ser a música escolhida por Walt Disney para musicar o filme Alô, Amigos - e esses "amigos" são, é claro, os latino-americanos representados pelo papagaio Zé Carioca. "O que é que a baiana tem?"(1938), tema do filme Banana da Terra, foi gravado por Carmen Miranda (não à toa, nossa maior "cantora de exportação") em 1931. Em 1941, os Anjos do Inferno gravam "Brasil Pandeiro", samba-exaltação de Assis Valente, também marcado pelo olhar (guloso?) do estrangeiro sobre a "terra do carnaval": "O Tio Sam está querendo conhecer a nossa batucada/Anda dizendo que o molho da baiana melhorou seu prato (...)/Na Casa Branca já dançou a batucada de ioiô e iaiá". (NOSSO SÉCULO, 1980, p. 148).
} 
de Alencar), a partir do qual se dará a "misturação" com o outro, ou seja, com o elemento "estrangeiro", fazendo dele também "gente de cô".

A própria grafia cabocla da canção remete-se a essa busca do que é original, um "jeito propriamente brasileiro de falar". No entanto, combinada com a voz impostada do cantor, provoca uma estranheza que certamente não é de todo casual: ao subverter a pureza da língua culta e simultaneamente respeitar a dicção imposta aos cantores de elite, o cantor desequilibra o tom unívoco de exaltação das "raízes" que a canção possui originalmente, mesclando e opondo, num mesmo movimento, cultura popular e erudita, o elemento mestiço e o europeu.

Em outro de seus sucessos da época, Orlando canta:

Eu nasci num clima quente
Você diz a toda gente
Que eu sou moreno demais
Não maltrates o teu pretinho
Que te faz tanto carinho
E no fundo é um bom rapaz
Você vem dum palacete
Eu nasci num barracão
Sapo namorando a lua
Numa noite de verão
Eu vou fazer serenata
Eu vou cantar minha dor
Meu samba vai, diz a ela
Que coração não tem cor.

Este samba de Marino Pinto e Wilson Batista se chama, é claro, "Preconceito". Desta vez, o quadro se inverte, e Orlando realiza uma espécie de paródia de si mesmo: o típico representante do "clima quente" é o mulato, desprezado pela moça rica por ser "moreno demais".

No verso seguinte, desfaz-se o eufemismo - bastante usual no linguajar brasileiro - da palavra "moreno", e o apaixonado pede para sua amada não maltratar o seu "pretinho", pois "no fundo (!) é um bom rapaz". O ideal, como em "Curare", continua sendo o da mestiçagem; no entanto, aqui, ao contrário daquela, a "misturação" não ocorre sem conflitos, que incluem tanto os preconceitos de raça quanto as diferenças sociais, estas expressas sobretudo no par antagônico palacete/barracão. 
Em comum, "Curare" e "Preconceito" possuem o dado evidente de narrarem histórias de amor ao mesmo tempo em que as relacionam, como vimos, com a metanarrativa de uma concepção de "brasilidade": a terra-mãe representada no corpo da mulher, o mito da mistura das raças, as diferenças sociais, os preconceitos étnicos.

E não apenas na música, mas em vários aspectos do discurso cultural brasileiro (incluindo, é claro, a literatura), podemos vislumbrar nas histórias de casais apaixonados imagens de inspiração patriótica, buscando, através da metáfora da mestiçagem, uma síntese do que representaria uma "essência nacional". Curioso paradoxo, esse que une nação à procura de uma essência, já que o próprio conceito de nação, como mostra Benedict Andersen, foi historicamente construído, podendo sua gênese ser mapeada com um grau razoável de precisão nos conflitos europeus do decorrer da Era Moderna (ANDERSON, 1996).

No caso do Brasil, espaço periférico às transformações que originaram os Estados-nações europeus, esse dilema entre a necessidade de se delinear uma imagem-síntese e as contradições históricas que a negam é ainda mais evidente. A experiência colonial de caráter mercantil, que buscava antes a exploração desmedida das riquezas das diferentes regiões que a integração entre as áreas americanas que compunham a larga extensão territorial de colonização portuguesa, não contribui em quase nada para essa busca da unidade: não estaríamos exagerando se disséssemos que, a despeito da existência de um Governo Geral para toda a colônia, o único fator de unidade do Brasil naqueles tempos era a língua. Às vésperas da independência, nem sentimentos nativistas nem interesses em comum faziam a ligação entre as distantes e atomizadas províncias - o caráter regionalista e separatista dos chamados "movimentos precursores da independência", incluindo a Inconfidência Mineira, são evidências bastante conhecidas dessa constatação.

Unificado de forma autoritária pelo príncipe-herdeiro do trono português e convertido a uma monarquia anacrônica (pois muito possuía ainda de Ancien Régime), o Brasil cambiou repentinamente da fragmentação colonial para a unificação sob a égide do cetro e da coroa imperiais. Isso não impediu, no entanto, que as tensões entre o local e o nacional continuassem existindo, 
levando até, em casos mais extremos, a persistência de desejos separatistas em várias regiões.

Não é à toa, portanto, que o período imperial foi o momento por excelência da criação do mito da nação brasileira, nos moldes da síntese romântica. Se, como sabiamente apontava Renan em fins do século XIX, "O esquecimento (...) também é um fator essencial na criação de uma nação" (Apud ROUANET, 1997, p. 19), era preciso obliterar toda uma realidade "indesejável” de multiplicidade, de estranhezas mútuas, de conflitos e de afastamentos numa imagem única, totalizante. A Iracema de Alencar resulta, talvez, no maior esforço empreendido na época para dar forma a este desejo de unidade das elites do Império, e foi tão bem-sucedida que ainda hoje, mais de cem anos após a deposição do segundo imperador pelo golpe republicano, expressa com inquietante (porque reducionista) exatidão a auto-imagem que grande parte dos brasileiros têm de sua terra, reproduzida em inúmeras variantes nos manuais escolares e nos meios de comunicação de massa.

No entanto, embora seja uma imagem predominante, a criação alencariana não se constitui na única que, ao "narrar a nação" (BHABHA, 1998) $)^{2}$, trata do par erótico-político. Outros movimentos literários, como o Naturalismo da virada do século e o Modernismo, ao se reapropriarem do mito de Iracema - aludindo, parafraseando, parodiando ou satirizando seus arcabouços teórico-discursivos -, também contribuíram para a configuração de sentimentos e ideias ambivalentes sobre o Brasil, as quais revelam, ao fim e ao cabo, os limites do próprio conceito de nacionalidade em sua forma essencialista.

Nosso objetivo neste ensaio seria, partindo do mito de Iracema, analisar dois outros momentos em que o tema da união mestiça serve de metáfora para a nação-narrativa - O Cortiço (1890) de Aluísio Azevedo e O Xangô de Baker Street (1995) de Jô Soares - relacionando-os aos discursos ideológicos que transitam no imaginário do país que olha para si próprio.

\section{Iracema - a narrativa da cordialidade}

2 Os chamados "estudos culturais" enfatizam a questão da nação como narrativa, como uma "comunidade imaginada" que é historicamente produzida através dos discursos político e literário. 
Em seu Ficções de Fundação, Doris Sommer se indaga o porquê dos chamados "romances de fundação" na América Latina - as narrativas que "fundam" uma dada concepção de nação que acaba por estabelecer-se como dominante - serem todos histórias de amor, pressupondo uma espécie de tradutibilidade alegórica entre uma linguagem de amor notavelmente coerente e um desenvolvimento nacional aparentemente linear e pacífico (SOMMER, 2004). Para Sommer, as interdições feitas à união dos amantes nos enredos dos romances fundadores relacionam-se às divisões sociais ou raciais do ambiente exterior que se resolvem indefectivelmente pela via da conciliação. Da mesma maneira, no nível político, a nação se apresenta como o espaço de consolidação de uma união livre de conflitos e desamores. Em suma, o movimento fundador nestes textos é o da síntese conciliatória, analogamente à da união sexual que funde dois corpos.

Em Iracema, romance de José de Alencar publicado em 1865 (portanto, no apogeu do $1{ }^{\circ}$ Império), a chave de leitura da nação, num momento histórico em que a questão da consciência nacional apenas começava a se formar como mostra Augusto Meyer, não havia ainda "lastro de tradições sedimentadas" (Apud: ALENCAR, 1965, p. 262) - é exatamente a da concilação, criando o mito do Brasil como união pacífica das raças.

Como um símbolo, Iracema oculta a violência da conquista colonial e as contradições do discurso emancipatório do Brasil do século XIX (...) a impedir que o negro pudesse protagonizar a cena romanesca ou representar parcela de identidade nacional. (...) Pintando Iracema como a indígena que se oferece de boa vontade ao colonizador e que, para isso, tem que trair seus compromissos com as tradições tribais, Alencar inverte os sinais da imposição colonizadora, abranda a violência do processo civilizador implantado e lança a semente da ideologia da conciliação pacífica de interesses divergentes. Deste modo, completa-se um circuito: a nação torna-se fruto da síntese conciliatória dos contrários, a identidade cultural símbolo desta união, e a história legitimação da versão oficial escrita pelo discurso da burguesia ascendente. (HELENA, 1995, p. 527)

Portanto, através da dialética memória/esquecimento, o romantismo de Alencar ressemantiza o movimento histórico fundador da nação - o encontro entre colonizador e colonizado -, camuflando a violência da conquista, recalcando a presença do elemento negro e obliterando os conflitos de 
interesses entre os grupos opostos. Iracema, síntese da natureza harmônica e virginal do Novo continente (Afrânio Peixoto já notara o anagrama de "América" no nome da "virgem dos lábios de mel"), Vênus indígena nascida num espaço e tempo míticos, "entra" no devir histórico no momento em que conhece Martim, o branco conquistador. Já neste primeiro encontro, quebra com ele a flecha da paz, dando boas-vindas ao estrangeiro (ALENCAR, s.d., p. 15.), o qual, a partir daí, entra na narrativa não como elemento destrutivo da nação indígena, mas como sujeito apaziguador de antigas querelas tribais.

No jogo de sedução que rapidamente se estabelece entre os protagonistas, a tensão entre a paixão que se intensifica e as interdições ao amor opõe a honradez de Martim, que reluta em satisfazer seus impulsos eróticos, ao "veneno" que emana do corpo de Iracema e ao feitiço da jurema, tentações diabólicas que o guerreiro branco busca afastar proferindo o nome do Deus cristão.

O cristão repeliu do seio a virgem indiana. Ele não deixará o rasto da desgraça na cabana hospedeira. Cerra os olhos para não ver, e enche sua alma com o nome e a veneração do seu Deus:

- Cristo!... Cristo!... (ALENCAR, s.d., pp. 57-58)

Portanto, quando ocorre a consumação do ato - a violação de Iracema não se trata propriamente de uma analogia à conquista violenta da terra pelo colonizador (como aliás, sugeriria a raiz etimológica do nome "Martim" como relacionada a Marte, deus da guerra): pelo contrário, a narrativa busca eximir este último de qualquer responsabilidade. A partir daí, todo o desenrolar da trama parece confirmar esta tendência inicial: é Iracema quem deve deslocarse para fora de seu ambiente original, traindo sua tribo e assinando sua sentença de morte. O sacrifício da protagonista ao final do romance é aceito por ela sem qualquer hesitação, pois acaba por se constituir, como mostra Alfredo Bosi (BOSI, 1992), na única saída para os fracos perante a "necessidade" da renovação civilizatória. Não a Iracema, mas a Moacir, o "filho do sofrimento" nascido no litoral como resultado da união mestiça, é permitida a sobrevivência, pois ele já é o ser híbrido destes dois mundos - o do colonizado e o do colonizador - representando a simbiose harmônica entre a natureza/feminino e a cultura/masculino. 
Mesmo quando Martim passa pelo ritual tribalista de batismo, não perde sua identidade original: em nenhum outro momento da narrativa posterior ao da cerimônia (capítulo XXIV) ele será chamado pelo nome indígena - Coatiabo. Portanto, apesar de travestido de nativo da terra, o "guerreiro branco" continuará a ter esse epíteto, não ingressando de fato na sociedade de origem de Iracema e Poti.

Este último, ao contrário, passa por uma transformação significativa ao final do romance:

\footnotetext{
Poti foi o primeiro que ajoelhou aos pés do sagrado lenho; não sofria ele que nada mais o separasse de seu irmão branco. Deviam ter ambos um só Deus, como tinham um só coração.

Ele recebeu com o batismo o nome do santo, cujo era o dia; e o do rei, a quem ia servir, e sobre os dois o seu, na língua dos novos irmãos (...). (ALENCAR, s.d., p. 120)
}

Ao contrário de Martim, que será apenas "pintado" de índio - e o nome "Coatiabo", formado pela aglutinação de coatiá (pintar) com aba (gente), confirma a hipótese da superficialidade da mudança - Poti, batizado como Antônio Filipe Camarão, será literalmente convertido: à religião do homem branco, unindo o ato de fé (da conversão à "palavra do Deus verdadeiro") a um ato de submissão (expresso no ajoelhar-se); à "língua dos novos irmãos", que traduz seu nome original; ao Império colonial, a quem passa a servir. O Outro se dilui no Mesmo ao ser renomeado, recalcando a alteridade e ressaltando a autoridade do conquistador perante os nativos da terra: daquele que conhece 0 Deus legítimo; daquele que maneja as forças do progresso e da ciência; daquele que possui a superioridade das armas.

Como tantos outros discursos que perpassavam a imaginação constituinte de nossas elites letradas da época, Iracema é um dos textos criadores do mito do "homem cordial", vendo numa "bondade natural" e na concórdia a essência do ser nacional, em contraposição ao racionalismo e individualismo burguês moderno.

O mito do homem cordial constrói-se, por assim dizer, numa espécie de "anti-Ética Protestante", seja para valorizar ou depreciar características que seriam próprias do Brasil. A polêmica entre Sérgio Buarque de Holanda e 
Cassiano Ricardo, entre as décadas de 30 e 40 do século passado, ilustra bem os dois sentidos principais da noção de cordialidade como traço predominante da cultura nacional. Para Cassiano Ricardo, o brasileiro, sendo por natureza mais cordial que os outros povos, estaria elaborando uma civilização "de fundo mais emotivo", o que levaria, necessariamente, a uma maior preocupação com o desenvolvimento igualitário e não-violento de toda a sociedade. A "bondade brasileira", para este autor, origina-se da própria riqueza de nossa terra, a qual, aliada à "pureza" do elemento indígena, constitui-se em terreno fértil para a conversão dos primeiros degredados que para cá vieram em "homens bons", que levam à frente uma espécie de "white man's burden" avant la lettre. Cassiano Ricardo nega o caráter predatório da colonização, substituindo o signo da violência pelo da conciliação:

No próprio drama da conquista, que muita gente pensa ter sido uma página rubra de destruição e crueldade, as coisas se passaram de modo diferente.

Podendo ter sido cruel como os demais conquistadores o brasileiro não o foi. Foi muito menos.

Alega-se, por exemplo, que o bandeirante escravizou, sacrificou o índio. Não é bem assim. Não raro, o bandeirante é um mediador, um apartador de briga entre os rivais. É o soldado pacificador do gentio, (...) conquista tribos e mais tribos, suavemente. (RICARDO, 1959, p. 27)

Desarmando os antagonismos, mais do que os provocando, o caráter nacional desenvolve uma "técnica de bondade", capaz de conciliar e neutralizar todos os conflitos - sociais, ideológicos, étnicos, econômicos. Como consequência, a mestiçagem e o sincretismo cultural seriam eles próprios processos de temperantia, de abrandamento das tensões em favor de uma "democracia social" superior à dos outros povos.

Em Raízes do Brasil, Sérgio Buarque critica o tratamento dado ao tema do "homem cordial" por Cassiano Ricardo, tanto em seu tom triunfalista quanto em seu caráter essencialista. Para Sérgio Buarque, a tradição brasileira historicamente formada numa colonização baseada no personalismo, na hierarquização, na aversão ao trabalho e na estruturação "feudal" da economia agro-exportadora - teria engendrado uma "cordialidade" que significa, grosso modo, a aversão às normas abstratas, às regras de polidez e civilidade e uma irresistível tendência à intimidade tanto na esfera privada quanto pública. A cordialidade seria, portanto, para Sérgio Buarque, não uma vantagem mas um 
entrave a qualquer tentativa de modernização racional do país, na medida em que extrapola os traços retrógrados, patriarcais e paternalistas da casa-grande à sociedade como um todo.

Nesse sentido, o discurso alencariano aproxima-se muito mais da visão reducionista de Cassiano Ricardo que da crítica feroz de Sérgio Buarque, embora ao tom apologético do autor de "O Homem Cordial" o romancista sobreponha um traço de melancolia: Iracema começa e termina com uma nota de tristeza, condicionando o "sucesso" do desbravamento das novas terras a serviço do Império português ao sacrifício da essência "pura" do nativo, representado por Iracema. O traço melancólico que costura início e fim do romance de Alencar revela as "falhas" do projeto de nação das elites imperiais, tornando problemática a celebração apoteótica do nacionalismo sincretista, tal como desejada por esses grupos.

\section{Retrato do cortiço, retrato do Brasil}

Em fins do século XIX, com a crise do regime monárquico e 0 consequente desmoronar da estrutura escravocrata no Brasil, a concepção da nação brasileira como espaço da harmonia idílica entre as raças passa por sérios questionamentos. Na literatura, esse momento de ruptura vai coincidir com a ascensão do Naturalismo, gênero que fazia sucesso na Europa, sobretudo através dos polêmicos romances dos franceses Flaubert e Zola e do português Eça de Queirós.

No Brasil, tão logo começaram a ser produzidas as primeiras manifestações do gênero, as críticas se fizeram ouvir. Contrapondo a estética naturalista às obras de um Alencar, as discussões se intensificavam em termos de se considerar a nova tendência literária como "moda" ou imitação de modelos estrangeiros, incapaz, portanto, de expressar a "originalidade nacional”. Já em artigo publicado em 1894, José Veríssimo faz uma cortante condenação do Naturalismo, tendo como base 0 argumento da mera importação de ideias:

Além de pobre de escritores e de obras, esse naturalismo é a menos nacional das nossas escolas literárias, e nenhum dos seus livros dá-nos a sensação da nossa sociedade e da nossa civilização. (VERÍSSIMO, 1894, p. 72) 
Alguns anos antes de Veríssimo, em O Naturalismo em Literatura, Sílvio Romero também não poupara munição contra o Naturalismo, quando adotado pelos autores nacionais:

O naturalismo, especialmente na ramificação empírica, só tem contado até aqui, na poesia, no romance e no drama, uns paspalhões mínimos de fazer dó. A glória da invenção da doutrina não Ihes pertence: é do estrangeiro. Cabe-lhes apenas a gloríola da imitação e esta mesma tão desjeitosa, tão inábil, tão mesquinha, que compunge. (ROMERO, Sílvio. 1882, p. 34).

O Naturalismo brasileiro é criticado por seus contemporâneos, portanto, tendo como base a oposição entre invenção e imitação. Que autenticidade, ou melhor, que Brasil um gênero importado poderia representar? O alcance desta discussão nos revela a importância que a construção literária de uma identidade nacional ainda tinha na época.

Hoje, superados pelo menos em grande parte os "traumas" decorrentes da percepção do Brasil como "cultura dependente", espaço das "ideias fora do lugar" (SCHWARZ, 1977), a discussão a respeito das relações entre as narrativas naturalistas e a questão da identidade nacional permanecem, ainda que em outro sentido. Argumenta-se, sobretudo, que a ambição naturalista de se constituir numa espécie de "transposição direta da realidade" invalidaria qualquer tentativa de se chegar a outros planos de significado.

Em artigo chamado "De cortiço a cortiço" (CANDIDO, 1993), Antonio Candido lança uma luz sobre a questão, reconhecendo que, embora grande parte dos textos naturalistas resuma-se de fato a uma espécie de "decalcamento" da realidade observável, alguns exemplos do gênero são, por outro lado, profícuos em significação alegórica. $O$ Cortiço, o mais bem realizado romance de Aluísio Azevedo, é considerado por Candido um exemplo claro desta constatação, pois, ao mesmo tempo que pode ser considerado 0 texto naturalista por excelência da literatura brasileira, pode ser também lido como alegoria do Brasil visto pelas lentes hipertrofiantes das elites intelectuais do fin de siécle oitocentista. De fato, o cortiço imaginado por Aluízio Azevedo representa inegavelmente um Brasil em miniatura, sob o ponto de vista pessimista do determinismo da época, que alia as teorias lombrosianas e do 
darwinismo social - a a respeito da inferioridade genética dos grupos étnicos mestiços e não-europeus - à suposição de um "enredamento" dos países tropicais, pela via de uma história de exploração predatória, ao destino de decadência.

Por isso, as principais histórias de amor narradas n'O Cortiço, sendo também romances de miscigenação, são trágicas e levam a uma degenerescência inevitável. Sob o sol escaldante dos trópicos, que incita ao ócio e à luxúria, os seres humanos animalizam-se, alheios às regras de civilização e conduta moral. O próprio cortiço é descrito, em sua formação, numa repugnante metáfora orgânica:

\begin{abstract}
E naquela terra encharcada e fumegante, naquela umidade quente e lodosa, começou a minhocar, a crescer, um mundo, uma coisa viva, uma geração, que parecia brotar espontânea, ali mesmo, daquele lameiro, e multiplicar-se como larvas no esterco. (AZEVEDO, s.d., p. 19)
\end{abstract}

Em meio a um povo degenerado, composto de negros e mulatos violentos e sensuais, ao elemento estrangeiro, "superior"3, aguardam duas possibilidades: a dominação tirânica da natureza desregrada - representada pela trajetória de João Romão - ou o abandono às condições locais - descrita na história de Jerônimo.

No primeiro caso, a "dominação do meio" reproduz a lógica da colonização mercantil. O envolvimento erótico entre João Romão e Bertoleza nunca deixará de ser uma relação senhor-escravo, no sentido mais cruel: a escrava negra irá servir obedientemente ao comerciante português, trabalhando de sol a sol enquanto este acumula riquezas; no momento em que se torna um estorvo para as ambições nobiliárias do novo-rico, sua única saída é a auto-imolação. Entretanto, aqui não se trata sequer do lírico sacrifício de Iracema, mas do destino abjeto ao qual, inexoravelmente, os desvalidos da nação são conduzidos.

\footnotetext{
${ }^{3}$ Em duas passagens do texto de Aluísio Azevedo é colocada literalmente a questão da superioridade do homem branco: na primeira, Bertoleza recebe de braços abertos o português "porque, como toda a cafuza, (...) não queria sujeitar-se a negros e procurava instintivamente o homem numa raça superior à sua" (C, pp. 11-12); na segunda, Rita Baiana, ao perceber que o hercúleo Jerônimo a desejava, abandona o mulato Firmo, pois "o sangue da mestiça reclamou seus direitos de apuração, e Rita preferiu no europeu o macho de raça superior" (C, p. 113). É importante observar que esses comentários se encontram no discurso do narrador, funcionando como índice de legitimação das elites na época.
} 
Enquanto isso, João Romão acaba por impor sua vontade transformadora ao regime caótico do cortiço: a geometrização do espaço e a expulsão dos moradores "indesejáveis", que ocorre ao fim do romance, são a realização do projeto autoritário do dominador estrangeiro, o triunfo do dirigido sobre o espontâneo, como nos mostra Candido (CANDIDO, 1993, pp. 134136). O cortiço deixa de ser descrito através da metáfora orgânica, e passa a ser concebido em termos mecânicos:

Mas o cortiço já não era mais o mesmo; estava muito diferente (...). O pátio, como João Romão havia prometido, estreitara-se com as edificações novas; agora parecia uma rua, todo calçado por igual e iluminado por três lampiões grandes, simetricamente dispostos (...). Desapareceram as pequenas hortas, os jardins de quatro a oito palmos e os imensos depósitos de garrafas vazias. À esquerda (...) estendia-se um novo correr de casinhas de porta e janela, e daí por diante (...) erguia-se um segundo andar, fechado em cima do primeiro por uma estreita e extensa varanda de grades de madeira, para a qual se subia por duas escadas, uma em cada extremidade. (...) notavam-se por último na estalagem muitos inquilinos novos, que já não eram gente sem gravata e sem meias. A feroz engrenagem daquela máquina terrível, que nunca parava, ia já lançando dentes a uma nova camada social que, pouco a pouco, se deixaria arrastar inteira lá para dentro. Começaram a vir estudantes pobres (...); surgiram contínuos de repartições públicas, caixeiros de botequim, artistas de teatro, condutores de bondes, e vendedores de bilhetes de loteria. (AZEVEDO, s.d., pp. 136-137)

Já o destino de Jerônimo, diferentemente da trajetória voluntarista de João Romão, traduz-se num movimento de dissolução da ação construtora no magnetismo do meio animalizante. Para Jerônimo, "abrasileirar-se", consequência necessária de sua paixão por Rita Baiana, é sucumbir à natureza luxuriosa e indolente da terra.

Passaram-se semanas. Jerônimo tomava agora, todas as manhãs, uma xícara de café bem grosso, à moda de Ritinha e tragava dois dedos de parati "prá cortar a friagem".

Uma transformação, lenta e profunda, operava-se nele, dia a dia, hora a hora, reviscerando-Ihe o corpo e alando-Ihe os sentidos, num trabalho misterioso e surdo de crisálida. A sua energia afrouxava-se lentamente: fazia-se contemplativo e amoroso. A vida americana e a natureza do Brasil patenteavam-lhe agora aspectos imprevistos e sedutores que o comoviam; esquecia-se dos seus primitivos sonhos de ambição, para idealizar felicidades novas, picantes e violentas; tornava-se liberal, imprevidente e franco, mais amigo de gastar que de guardar; adquiria desejos, tomava gosto aos prazeres, e volviase preguiçoso resignando-se, vencido, às imposições do Sol e do calor, muralha de fogo com que o espírito eternamente revoltado do 
último tamoio entrincheirou a pátria contra os conquistadores aventureiros.

E assim, pouco a pouco, se foram reformando todos os seus hábitos singelos de aldeão português; e Jerônimo abrasileirou-se. (...) quanto mais ia ele caindo nos usos e nos costumes brasileiros, tanto mais os seus sentidos se apuravam, posto que em detrimento das suas forças físicas. (AZEVEDO, s.d., p. 63)

Assim como João Romão, o objetivo original de Jerônimo, ao deixar Portugal, era "fazer o Brasil". Ao contrário daquele, no entanto, o cavouqueiro permitirá que o "Brasil o faça": de homem trabalhador, sério, de hábitos frugais, voltado para o bem da família, passa ao esbanjamento e à indolência, à promiscuidade e à irresponsabilidade. Com isso, nivela-se à brutalidade do povo mestiço: nisto, mais que tudo, consiste o processo de "abrasileiramento" que o levará à ruína.

O pessimismo determinista de $O$ cortiço lembra, em muitos aspectos, uma importante vertente da historiografia positivista brasileira, que possui, entre seus nomes, Capistrano de Abreu no século XIX e Paulo Prado no século $X X$. As relações que podem ser delineadas entre o romance de Aluísio Azevedo e Retrato do Brasil, por exemplo, vão além da constatação óbvia de ambos buscarem fazer um "retrato" do Brasil, rompendo o véu ufanista de defesa de uma fictícia "superioridade nacional" para revelar as mazelas da sociedade. Os dois textos aproximam-se ainda numa hipótese fundamental em comum: a visão do Brasil como um organismo acometido de severa "doença moral", perigosamente arraigada na tradição e obliterada por uma auto-imagem superestimada herdada do Romantismo. No entanto, se no texto ficcional essa "doença" - representada sobretudo pela depravação dos costumes - é parte integrante das condições mesológicas, mais que de um processo histórico baseado na espoliação violenta da terra e dos grupos dominados (embora, como vimos acima, este traço não deixe de aparecer no romance de Aluísio Azevedo), no ensaio de Paulo Prado é, de fato, a consequência mais séria de um processo colonizador baseado não no desenvolvimento da colônia, mas na luxúria e na cobiça, levando a um sentimento generalizado de tristeza em meio a uma terra exuberante.

Numa terra radiosa vive um povo triste. Legaram-Ihe essa melancolia os descobridores que a revelaram ao mundo e a povoaram. O esplêndido dinamismo dessa gente rude obedecia 
a dois grandes impulsos que dominam toda a psicologia da descoberta e nunca foram geradores de alegria: a ambição do ouro e a sensualidade livre e infrene que, como culto, a Renascença fizera ressuscitar. (PRADO, 1972, p. 149)

No entanto, ainda que Paulo Prado procure ressaltar as "raízes históricas" de tal doença, não deixa também de "culpar", como o autor d'O cortiço, as condições naturais e a formação étnica do país pelos "vícios e crimes" que compõem o cenário nacional:

O clima, o homem livre na solidão, o índio sensual, encorajavam e multiplicavam as uniões de pura animalidade. (...) Para homens que vinham da Europa policiada, o ardor dos temperamentos, a amoralidade dos costumes, a ausência do pudor civilizado - e toda a contínua tumescência voluptosa da natureza virgem - eram um convite à vida solta e infrene em que tudo era permitido. (...) Do contato desta sensualidade com o desregramento e a dissolução do conquistador europeu surgiram as nossas primitivas populações mestiças. Terra de todos os vícios e de todos os crimes. (PRADO, 1972, pp. 158160).

Assim, o pecado da cobiça, trazido pelo colonizador que busca o enriquecimento fácil, é potencializado pelo pecado da luxúria que reside, desde sempre, na sensualidade latente das filhas da selva americana (como a mulata Rita), que incentiva as uniões "de pura animalidade":

\begin{abstract}
Naquela mulata estava o grande mistério, a síntese das impressões que ele recebeu chegando aqui: ela era a luz ardente do meio-dia; ela era o calor vermelho das sestas da fazenda; era o aroma quente dos trevos e das baunilhas, que 0 atordoara nas matas brasileiras; era a palmeira virginal e esquiva que não se torce a nenhuma outra planta; era 0 veneno e era o açúcar gostoso; era o sapoti mais doce que o mel e era a castanha do caju, que abre feridas com seu azeite de fogo; ela era a cobra verde e traiçoeira, a lagarta viscosa, a muriçoca doida, que esvoaçava havia muito tempo em torno do corpo dele, assanhando-lhe os desejos, acordando-lhe as fibras embambecidas pela saudade da terra, picando-lhe as artérias, para the cuspir dentro do sangue uma centelha daquele amor setentrional, uma nota daquela música feita de gemidos de prazer, uma larva daquela nuvem de cantáridas que zumbiam em torno de Rita Baiana e espalhavam-se pelo ar numa fosforescência afrodisíaca. (AZEVEDO, s.d., p. 54)
\end{abstract}

Através do movimento lúbrico da sedução da mulher nativa, Jerônimo é derrubado, invertendo-se o destino de Iracema: desta vez a terra, elemento 
feminino, tem "curare no corpo", veneno que acaba por vencer e inibir a ação construtiva e racional sobre a realidade.

\section{Sherlock nos trópicos}

Hoje, num momento em que o processo de globalização dilui as fronteiras dos Estados-nações e aponta para a integração de comunidades e organizações em escala planetária, o debate a respeito das identidades nacionais soa como ultrapassado. No entanto, ao mesmo tempo em que se acelera enormemente o ritmo da integração global a partir de meados da década de 70, assistimos ao reforço de determinadas identidades - nacionais, locais ou particularistas - , como resistência ao processo de homogeneização cultural do "pós-moderno global"4. Portanto, seja pela via do embate contra a dominação autoritária de etnias majoritárias ou regiões dominantes (como no caso do esfacelamento dos Estados do Leste europeu após a derrocada do socialismo autoritário, dos conflitos entre Inglaterra e Irlanda, dos movimentos separatistas do país basco, das guerras civis que arrasam os países africanos), seja pela via da constituição de outras identidades (através, por exemplo, do fundamentalismo islâmico, da "cultura da diáspora", do hibridismo cultural, dos movimentos de gênero) parece haver nos dias atuais um revival das discussões a respeito da questão das identidades e suas relações com um território delimitado, capaz de incorporar em termos geográficos o desejo de pertencimento a uma determinada comunidade.

No Brasil, país absolutamente singular no que se refere à ausência de maiores conflitos políticos entre as diversas regiões que compõem um vastíssimo território - e apesar da significativa pluralidade de identidades diferentes no interior das fronteiras do país - as tensões entre o local e o nacional deslocam-se, mais do que nunca, à esfera da cultura. A persistência do regionalismo nas artes, por exemplo, muitas vezes revela o caráter exóticopara-nós-mesmos da diversidade cultural brasileira, enquanto a postura propositadamente cosmopolita e anti-ufanista de alguns intelectuais e artistas

\footnotetext{
4 Em A identidade cultural na pós-modernidade, Stuart Hall aponta para o que ele chama de "paradoxo da modernidade": o processo simultâneo de desintegração e reforço das identidades no quadro da globalização. (HALL, Stuart. 1998, pp. 67-97)
} 
reaviva a discussão a sobre o "desrespeito às raízes" e à "herança verde-eamarela".

Nesse quadro de esfacelamento do sentimento unívoco de pertencimento a uma comunidade nacional, como definir a nação, e ainda por cima através de uma literatura nacional, sem recorrer à tautologia: "A literatura brasileira, isto é, a literatura produzida no Brasil, define o Brasil"? Por isso, antes de arriscar qualquer interpretação, é preciso que tenhamos em mente que, como hoje não é mais possível recuperar a identidade nacional, a partir de critérios normativos e excludentes entre "boa" e "má" literatura, ou entre "literatura genuinamente nacional" e imitação do estrangeiro, toda escolha será necessariamente arbitrária e sem a pretensão da totalidade, de esgotar ou sintetizar a plurivocalidade de discursos que caracterizam a pós-modernidade.

Já é notório que, na literatura brasileira contemporânea, duas tendências - o romance histórico e as narrativas policiais - aparecem como dominantes, enfatizando tanto a circulação recorrente de determinadas ideias entre a "república das letras" quanto às mudanças no gosto do público-leitor nos últimos tempos. Ironicamente, a ascensão concomitante destas duas tendências parece contraditória, na medida em que, se o sucesso da segunda vem ao encontro de um diálogo com o exterior - não havia até há pouco tempo, por assim dizer, uma "tradição" de textos do gênero no Brasil - a primeira revela a necessidade, ainda presente, de um "auto-entendimento" da formação histórica da nação, ou seja, de suas "raízes".

O Xangô de Baker Street, romance de estréia do humorista Jô Soares, une essas duas tendências: em linhas gerais, é uma tradicional narrativa de enigma, protagonizada pelo famoso detetive Sherlock Holmes, ambientada no Brasil da segunda metade do século XIX. O que há de original aqui não é tanto o tema, mas a forma como o autor conduz a narrativa, pois o recurso ao humor desmonta certas convenções que ainda persistem na literatura brasileira sobretudo aquela subsidiária do sucesso do Naturalismo como gênero, que 
defende a exatidão documental na reprodução da realidade histórica e social para que se possa de fato "compreender" o Brasil"

Misturando figuras históricas a personagens de ficção (incluindo um protagonista "roubado" de Arthur Conan Doyle), incluindo em vários momentos do texto enganadoras explicações etiológicas (como a invenção da caipirinha por Watson e do neologismo serial killer por Holmes), incorrendo em falsidades históricas, Jô Soares realiza a inversão paródica tanto dos estilos literários que maneja quanto das obsessões por uma definição precisa do caráter nacional, que assombram a literatura brasileira desde o indianismo romântico. Pois o Xangô não deixa de ser, em larga medida, uma sátira ao mito de Iracema, ora reproduzindo ora embaralhando seus principais componentes. Como nos dois outros textos analisados aqui, o livro de Jô Soares é, também, uma história de amor e miscigenação, microcosmo da nação brasileira em seu movimento fundador.

É curioso notarmos, antes de tudo, a escolha de Sherlock Holmes como protagonista do romance. Embora indubitavelmente o personagem de Conan Doyle, em sua evidente inverossimilhança, seja um prato cheio para a deformação caricatural, Jô Soares vai além, contrapondo o lado patético da existência humana ao cérebro absolutamente lógico do detetive britânico.

Para começar, as famosas deduções que fazem a alegria dos fãs de Holmes estão todas equivocadas no livro de Jô; por mais que se esforce, o detetive não consegue solucionar o mistério dos crimes cometidos em terras brasileiras (o roubo do Stradivarius e os assassinatos em série); seus raciocínios são diversas vezes suplantados por outros personagens, incluindo aqueles de status inferior ao seu (o negro, a mulher, o pobre etc.). Por isso, ao contar a aventura de Holmes que não irá entrar em suas memórias coligidas pelo Dr. Watson - a única em que ele teria fracassado - o livro pode ser lido em dois sentidos: na crítica mordaz ao racionalismo cartesiano, na medida em que se afasta da experiência no mundo, e numa possível inversão da lógica no espaço dos trópicos. Nesse caso, o atrapalhado detetive de Jô estaria certo em dizer que suas suposições estão sempre corretas, e não devem ser

\footnotetext{
${ }^{5}$ Curiosamente, outrora criticada, a estética naturalista prevaleceu na literatura brasileira como forma de reprodução "filial" da origem, do "ser nacional". Cf. Flora Süssekind, já em sua excelente dissertação de mestrado, analisando a recorrência do Naturalismo como uma reprodução do Brasil "tal e qual". (SÜSSEKIND,1982)
} 
empanadas "por vulgares pormenores" (SOARES, 1995, p. 219): a realidade do Brasil é que estaria além de qualquer explicação.

Outro dado delicioso na composição do personagem está no fato de ele se expressar num corretíssimo português lisboeta, que aprendera anos antes em Macau. Este detalhe intensifica os nexos entre o sério e o ridículo na busca da origem nacional europeia, pois ao mesmo tempo em que se aproxima das figuras canônicas dos conquistadores estrangeiros em nossas narrativas de fundação - incluindo o Martim de Iracema e o Jerônimo de O Cortiço - dá margem às inevitáveis piadas sobre o falar lusitano, atos de rebeldia filial contra o pai autoritário.

Como Martim e Jerônimo, o Sherlock Holmes de Jô Soares também será arrebatado pela paixão por uma mulher mestiça, chamada Anna Candelária, e transformado através do amor. No entanto, ao contrário do que ocorre com Jerônimo, o processo pedagógico de "abrasileiramento" terá uma orientação mais positiva que negativa: embora o calor dos trópicos 0 induza necessariamente à lassidão, aos excessos gastronômicos - como na hilariante passagem do banquete à base de vatapá e feijoada, que provoca posteriormente um terrível mal-estar no "herói" (SOARES, 1995, pp. 114-117) e a descoberta da luxúria, Holmes retorna a Londres mais humanizado.

Diferente do que ocorre em Iracema e $O$ cortiço, o ato sexual entre os dois apaixonados de $O$ Xangô de Baker Street nunca se consuma, e o detetive volta a sua terra natal ainda virgem - o que aponta para a impossibilidade de realização harmônica da mestiçagem. Mesmo assim, o detetive torna-se cada vez mais "amulatado" em seus hábitos, trocando a pesada capa de lã pelo terno de linho branco e a excitação cerebral da cocaína pelo poder letárgico da cannabis sativa. Transitando pelos vários espaços da cidade do Rio de Janeiro, ainda colonial em vários aspectos, assombra-se com o fosso entre as sofisticadas tardes de domingo no Jockey Club e o primitivismo mágico dos rituais africanos no morro da Gamboa. Assim, não realiza apenas uma cartografia da Capital Federal nos tempos do II Império, mas lança sobre ela uma indagação: que Brasil?

Portanto, ao mesmo tempo em que, numa leitura superficial, o livro de Jô parece reproduzir ingenuamente o discurso da cordialidade, das belezas 
naturais do país e do magnetismo do estrangeiro pelo exótico, também é capaz de, através do riso, apontar para as profundas fissuras de uma sociedade predominantemente negra e mestiça que se moderniza pela ação autoritária do monarca de educação europeia. Impossível esquecermos, dentre tantas passagens hilárias do livro, a mais precisa (e séria) imagem de nação que ele contém: a fotografia de D. Pedro, vestindo um manto de papos de tucano sobre o uniforme de gala, cercado de índios nus. Imagem que retorna a Alencar, à história de amor entre a nua Iracema e o guerreiro branco "Coatiabo": a nação conciliadora dos opostos, tal como concebida pelas elites do Império.

\section{Referências:}

1. ALENCAR, José de. Iracema: lenda do Ceará. São Paulo: Melhoramentos, s.d, $10^{\mathrm{a}}$ ed.

2. ANDERSON, Benedict. "Introduction". In: BALAKRISHNAN, Gopal (ed.).Mapping the nation. London/New York: Verso/New Left Rewiew, 1996.

3. AZEVEDO, Aluízio. O cortiço. Rio de Janeiro: Ediouro, s.d.

4. BHABHA, Homi. O local da cultura. Belo Horizonte: EdUFMG, 1998.

5. BOSI, Alfredo. "Um mito sacrificial: o indianismo de Alencar". In: Dialética da colonização. São Paulo: Companhia das Letras, 1992.

6. CANDIDO, Antonio. "De cortiço a cortiço". In: O discurso e a cidade. São Paulo: Duas Cidades, 1993.

7. CASTRO, Rui. "Caprichos do Destino". In: O cantor das multidões: Orlando Silva. Gravações originais 1935-1942. BMG-Ariola, 1987.

8. HALL, Stuart. A identidade cultural na pós-modernidade. Rio de Janeiro: DP\&A, 1998.

9. HELENA, Lúcia. "Escrevendo a nação". In: IV Congresso da ABRALIC: Literatura e diferença. Anais. São Paulo: ABRALIC, 1995.

10. HOLANDA, SÉRGIO Buarque de. Raízes do Brasil. Rio de Janeiro: José Olympio, $1981,14^{\mathrm{a}}$ ed.

11. MEYER, Augusto. "Alencar". In: A Chave e a máscara. Apud: ALENCAR, José de. Iracema: edição do centenário. Org. M. Cavalcanti Proença. Rio de Janeiro, José Olympio, 1965. 
12. NOSSO SÉCULO. 1930-1945: A Era de Vargas. São Paulo: Abril Cultural, 1980.

13. PRADO, Paulo. "Retrato do Brasil". In: Província e Nação Paulística/Retrato do Brasil. Rio de Janeiro: José Olympio, 1972.

14. RICARDO, Cassiano. "O homem cordial". In: O homem cordial e outros pequenos estudos brasileiros. Rio de Janeiro: MEC/INL, 1959.

15. ROMERO, Sílvio. O Naturalismo em Literatura. São Paulo: Tipografia da Província de São Paulo, 1882.

16. ROUANET, Maria Helena (org.). Nacionalidade em questão. Cadernos da Pós/Letras. Rio de Janeiro: Ed. da UERJ, 1997.

17.SCHWARZ, Roberto. "As idéias fora do lugar". In: Ao vencedor as batatas. São Paulo: Duas Cidades, 1977.

18.SOARES, Jô. O Xangô de Baker Street: romance. São Paulo: Companhia das Letras, $1995,3^{\mathrm{a}}$ reimp.

19.SOMMER, Doris. Ficções de fundação. Os romances nacionais da América Latina. Belo Horizonte, 2004.

20. SÜSSEKIND, Flora. Tal Brasil, qual romance? Dissertação de Mestrado. Departamento de Letras. Rio de Janeiro: PUC-Rio, 1982.

21. VERÍSSIMO, José. "O Naturalismo na Literatura Brasileira". In: Estudos Brasileiros $2^{a}$ série (1889-1893). Rio de Janeiro/São Paulo: Laemmert e C. Ed., 1894. 